\title{
Microbicidal activity of crude extracts from Sargassum wightii against Bacillus cereus
}

\author{
Amritha Krishna Bhuvaneshwari Venugopal1, *Vinoth Kumar Thirumalairaj ${ }^{1}$, Geetharamani Durairaj², Mahitha Puthan- \\ purayal Vijayan ${ }^{1}$, Navya Lazar ${ }^{1}$, Kavya Kurumboor Sathyan ${ }^{1}$, Amrutha Chacko ${ }^{1}$, Rincy Yesudas ${ }^{1}$, Shasna Kadheeja ${ }^{1}$, \\ Ishara Kumari John David'1, Sezirahiga Jean Damascene ${ }^{1}$ \\ ${ }^{1}$ School of Biological Sciences, CMS College of Science E Commerce, Coimbatore-641 049, Tamil Nadu, India \\ ${ }^{2}$ Department of Microbiology, Dr. NGP Arts and Science College, Coimbatore-641048, Tamil Nadu, India
}

\begin{abstract}
The present study was investigated to explore the antibacterial activity of four different solvent (petroleum ether, chloroform, acetone and ethanol) crude extracts of marine brown seaweed Sargassum wightti. Crude extracts were screened against human pathogen Bacillus cereus. The antibacterial efficiency was performed by agar well diffusion, minimum inhibitory concentration (MIC) and minimum bactericidal concentration (MBC) methods. The results revealed that the crude extract of petroleum ether showed prominent inhibiting activity against $B$. cereus and other crude extracts showed below detectable level. The highest microbicidal activity (zone of inhibition) $9.0 \pm 0.32 \mathrm{~mm}$ was obtained at the concentration of $250 \mu \mathrm{g} / \mathrm{ml}$ and the lowest activity was $3 \pm 0.20 \mathrm{~mm}$ at $31.25 \mu \mathrm{g} / \mathrm{ml}$ concentration. The MIC and MBC values were found to be 125 and $250 \mu \mathrm{g} / \mathrm{ml}$ respectively. Results of this study suggested that the compounds present in the crude extracts of petroleum ether showed high activity against B. cereus and further studies are required to purify the active principles.
\end{abstract}

Key Words: Seaweed, antibacterial activity, pathogen, microbicide, solvents.

\section{INTRODUCTION}

World Health Organization (2004) reported that infectious diseases are a major cause of morbidity and mortality worldwide and bacterial infection causes high rate of mortality in human population (Farias et al., 2000). The enhanced treatment of infectious diseases by microbicide has limitations because of its changing patterns of resistance in pathogens and side effects. These limitations demand for the identification of new antimicrobial compounds derived from natural sources especially from marine (Ballantine et al., 1987).

Marine seaweeds are rich source of structurally novel and biologically active metabolites. Secondary and primary metabolites isolated from seaweeds are potentially active in the pharmaceutical industry against human and other diseases (Farias et al., 2000). Most of the secondary metabolites of marine seaweeds such as flavonoids, terpenoids, alkaloids and phenolic compounds show wide range of anti-bacterial activities against the human pathogens (Thirumaran et al., 2006) and recent research implies that polysaccharides like inulin, oligo-fructose, galacto oligosaccharides and lactilose can also act as potent prebiotic compounds against pathogenic microbes in humans.

The antimicrobial activity of seaweeds in the coastal area of Tamil Nadu is still needs to be explored. Sargassum wightii belongs to brown seaweeds and are widely found in south Indian coastal belt with remarkable biological activities.

Bacillus cereus is a Gram-positive, rod-shaped aerobic bacterium with endospore (Todar, 2008) and can multiply

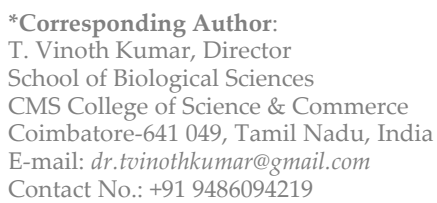

quickly even at room temperature. B. cereus is responsible for a minority (2-5\%) of food borne diseases (Todar, 2008; Davis, 2010), causing severe nausea, vomiting and diarrhea, aggressive than necrotizing fasciitis. Food poisoning is a major health problem, affecting both industrialized and developing countries.

Objective of the present study was to screen the crude solvent extracts of $S$. wightii against the food borne pathogen B. cereus.

\section{MATERIALS AND METHODS}

\section{Antibacterial assays}

Bacterial culture

B. cereus was collected from the Rajah Muthiah Medical College, Annamalai University, Tamil Nadu, India. Collected strain was grown in Trypticase soy-polymyxin broth under aerobic conditions at $37^{\circ} \mathrm{C}$ in a rotary shaker at $200 \mathrm{rpm}$ to reach exponential growth.

\section{Screening of antibacterial activity}

Crude petroleum ether, chloroform, acetone and ethanol extracts of the seaweed $S$. wightii were obtained by sequential solvent extraction method using a soxhlet. The antibacterial activity of crude extracts was performed by agar plate well diffusion assay on Mueller Hinton Agar (Marudhupandi and AjithKumar, 2013). Mueller Hinton agar media was prepared, sterilized and poured into sterile Petri dishes. Wells of $6 \mathrm{~mm}$ diameter were made on the agar plates by using sterilized well cutter. Inoculum in exponential phase of growth, equivalent to a $0.5 \mathrm{McFar}-$ land standard was swabbed on to the surface of the agar. Crude extracts of the solvents (petroleum ether, chloroform, acetone and ethanol) were prepared and dispensed in to the wells in the concentrations ranging from 250,125, 61.5 and $31.25 \mu \mathrm{g} / \mathrm{ml}$. The plates were then incubated at $37^{\circ} \mathrm{C}$ for $24 \mathrm{~h}$. The antibacterial activity of the crude extracts was determined by observing the diameter of zone of inhibition (in $\mathrm{mm}$ ) on the plates. 
Table 1: Diameter of Zone of inhibition (in $\mathrm{mm}$ ) produced by the crude solvent extracts of $S$. wightii against $B$. Cereus.

\begin{tabular}{ccccc}
\hline \multirow{2}{*}{$\begin{array}{c}\text { Concentration of } \\
\text { extract }(\mu \mathrm{g} / \mathrm{ml})\end{array}$} & \multicolumn{4}{c}{ Diameter of zone of inhibition (in mm) } \\
\cline { 2 - 5 } & $\begin{array}{c}\text { Petroleum } \\
\text { ether }\end{array}$ & $\begin{array}{c}\text { Chloro- } \\
\text { form }\end{array}$ & Acetone & Ethanol \\
\hline 31.25 & $8.0 \pm 0.20$ & - & - & - \\
62.5 & $10.4 \pm 0.10$ & - & - & - \\
125 & $12.2 \pm 0.20$ & - & - & - \\
250 & $14.0 \pm 0.32$ & - & - & - \\
\hline
\end{tabular}

\section{Determination of Minimum Inhibitory Concentrations}

To determine the minimum inhibitory concentration (MIC) of the crude extracts of $S$. wightii tube dilution technique was employed. This test was done to determine the lowest concentration of crude extracts that inhibit the growth of bacteria. A loop full of exponential phase bacterial culture corresponding to 0.5 Macfarlands opacity was inoculated in to nutrient broth with different concentration of extracts ranging from 125, 62.5, 31.25 and $15.625 \mu \mathrm{g} / \mathrm{ml}$. The tubes were then incubated at $37^{\circ} \mathrm{C}$ for $24 \mathrm{~h}$. Turbidity was observed after the incubation period. MIC was defined as the lowest concentration of crude extract that completely inhibited the visible growth of the test microorganisms.

\section{Minimum bactericidal concentration}

To determine minimum bactericidal concentration (MBC), one loop full of the sample corresponding to MIC and the next higher concentrations were streaked individually on nutrient agar and incubated at $37^{\circ} \mathrm{C}$ for $18 \mathrm{~h}$. The lowest concentration of extract that showed no bacterial growth on agar plate represents the MBC value of the particular extract.

\section{Statistical analysis}

The experiments were conducted in triplicates and the results were expressed as mean \pm S.E.M. Statistical analysis were performed with Sigma plot ${ }^{\circledR} 12.5$ software, Systat, USA.

\section{RESULTS AND DISCUSSION}

Seaweeds serve as an important source of bioactive natural substances (Metzger et al., 2002). S. wightii is one of the marine brown seaweed species, with tremendous biological applications and are known to be rich in sulphated polysaccharides content and these sulphated polysaccharides were found to possess wide range pharmacological and biomedical properties (Guven et al., 1999), especially antimicrobial activity against human pathogens like B. cereus.

Antibacterial activity of the crude solvent extracts was performed against the bacterial pathogen $B$. cereus by agar well diffusion method. The maximum antibacterial activity of $14.0 \pm 0.32 \mathrm{~mm}$ was found to be exhibited by the crude petroleum ether extract and other crude extracts of chloroform, acetone and ethanol exhibited no detectable activity against $B$. cereus.

The minimum inhibitory concentration and minimum bactericidal concentration of crude petroleum ether extract was $62.5 \mu \mathrm{g} / \mathrm{ml}$ and $125 \mu \mathrm{g} / \mathrm{ml}$ respectively against $B$. cereus. The minimum bactericidal concentration was showed as $31.25 \mu \mathrm{g} / \mathrm{ml}$ against $B$. cereus.

Antibacterial activity of brown seaweeds against Gram positive bacteria has been extensively studied by Kolanjinathan and Stella (2009). The extraction methods, solvents and seasonal variation play an important role in the microbicidal activities (Kandhasamy and Arunachalam,
2008). Kim and Lee (2008) used methanolic extracts of Sargassum sp. which showed strong antibacterial activities against Methicillin-resistant Staphylococcus aureus (MRSA) strains. Rajasekar et al. (2014) indicated that acetone was the best solution for extracting the effective antimicrobial materials from Sargassum myricystum, Turbinaria conoides, and Gracilaria edulis; whereas, Karthikaidevi et al. (2009) used seven different solvents including chloroform and ethanol for extraction of antibacterial substances from Ulva reticulata and Halimeda tuna.

In this study, four extracts of different solvent extracts of $S$. wightii were screened for the antibacterial activity against the human pathogen $B$. cereus. The results showed that, petroleum ether extract of $S$. wightii showed high activity against $B$. cereus compared to the other extract and the MIC and MBC value was found to be 62.5 and $125 \mu \mathrm{g} / \mathrm{ml}$, respectively against $B$. cereus. The compounds present in the petroleum ether extract which exhibits high antibacterial activity against $B$. cereus should be purified and characterized completely to explore its potential application as food preservative.

\section{ACKNOWLEDGEMENT}

The authors are thankful to the authorities of CMS college of Science and Commerce and Dr. NGP Arts and Science College, Coimbatore, Tamil Nadu, India for their facilities.

\section{REFERENCES}

Ballantine DL, Gerwick WH, Velez SM, Alexander E, Guevara P (1987)

Antibiotic activity of lipid- soluble extracts from Caribbean Marine Algae. Hydrobiol 1511152: 463-469. [DOI]

Davis CP (2010) Listeriosis (Listeria monocytogenes Infection). What is listeriosis? [Link]

Farias WRL, Valente AP, Pereire MS, Mourao PAS (2000) Structure and anticoagulant activity of sulfated galactans: Isolation of a unique sulfated galactan from the red algae Botryocladia occidentalis and comparison of its anticoagulant action with that sulfated galactans from invertebrates. J Biol Chem 275: 29299-29307. [DOI]

Guven KCB, Guvener Guler E (1999) Pharmacological activities of marine algae. In I. Akatsuka (ed.). Introduction to Applied Phycology, SPB Academic Publishing by The Hague, Netherlands. pp. 67-92.

Kandhasamy M, Arunachalam KD (2008) Evaluation of in vitro antibacterial property of seaweeds of southeast coast of India. Afr J Biotechnol 7(12): 1958-1961.

Karthikaidevi G, Manivannan K, Thirumaran G, Anantharaman P Balasubaramanian T (2009) Antibacterial Properties of Selected Green Seaweeds from Vedalai Coastal Waters; Gulf of Mannar Marine Biosphere Reserve. Global J Pharmacol 3(2): 107-112.

Kim IH, Lee JH (2008) Antimicrobial activities against methicillin-resistant Staphylococcus aureus from macroalgae. J Ind Eng Chem 14: 568-572. [DOI]

Kolanjinathan K, Stella D (2009). Antibacterial activity of marine macro algae against human pathogens. Recent Res Sci Technol 1(1): 20-22.

Marudhupandi T, AjithKumar TT (2013) Antibacterial effect of fucoidan from S. wightii against the chosen human bacterial pathogens. Int Curr Pharm J 2(10): 156-158. [DOI]

Metzger P, Roger MN, Largean C (2002) Botryolins A and B, two tetramethyl sequalene triethers from the green microalga Botryoccus braunic. Phytochem 59: 839-843. [DOI]

Rajasekar T, Priyadharshini P, Kumaran S, Deivasigamani B, Sakthivel M, Balamurugan S, George EGJ (2014) Screening of marine seaweeds for bioactive compound against fish pathogenic bacteria and active fraction analysed by gas chromatography- mass spectrometry. J Coast Life Med 2(5): 367-375. [DOI]

Thirumaran G, Vijayabaskar P, Anantharaman P (2006) Antibacterial and antifungalactivies of brown Marine macro alaga (Dictyota dichotoma) from the Gulf of mannar biosphere reserve. Environ Ecol $24 S$ (1): 37-40.

Todar K (2008) Bacillus cereus Food Poisoning. [Link]

WHO (2004) The world health report. Changing history. Statistical annex Death by cause, sex and mortality stratum in WHO regions, estimates for 2002. Geneva, Switzerland WHO; pp. 120-121. 